University of Nebraska - Lincoln

DigitalCommons@University of Nebraska - Lincoln

\title{
Effects of Concentration and Composition of Wet Corn Gluten Feed in Steam-Flaked Corn-Based Finishing Diets
}

\author{
C. N. Macken \\ University of Nebraska-Lincoln \\ Galen E. Erickson \\ University of Nebraska-Lincoln, gerickson4@unl.edu \\ Terry Klopfenstein \\ University of Nebraska-Lincoln, tklopfenstein1@unl.edu \\ Rick Stock \\ University of Nebraska-Lincoln, rstock3@Unl.edu
}

Follow this and additional works at: https://digitalcommons.unl.edu/animalscifacpub

Part of the Animal Sciences Commons

Macken, C. N.; Erickson, Galen E.; Klopfenstein, Terry; and Stock, Rick, "Effects of Concentration and Composition of Wet Corn Gluten Feed in Steam-Flaked Corn-Based Finishing Diets" (2004). Faculty Papers and Publications in Animal Science. 470.

https://digitalcommons.unl.edu/animalscifacpub/470

This Article is brought to you for free and open access by the Animal Science Department at DigitalCommons@University of Nebraska - Lincoln. It has been accepted for inclusion in Faculty Papers and Publications in Animal Science by an authorized administrator of DigitalCommons@University of Nebraska - Lincoln. 


\title{
Effects of concentration and composition of wet corn gluten feed in steam-flaked corn-based finishing $\operatorname{diets}^{1}$
}

\author{
C. N. Macken*, G. E. Erickson*2, T. J. Klopfenstein*, and R. A. Stock $\dagger$ \\ *Department of Animal Science, University of Nebraska, Lincoln 68583-0908; and \\ $\dagger$ Cargill Inc., Blair, NE 68008
}

\begin{abstract}
Two finishing experiments were conducted to determine the effects of concentration (Exp. 1) and composition of wet corn gluten feed (Exp. 2) in steam-flaked corn-based diets on feedlot steer performance. In Exp. 1, 192 English $\times$ Continental crossbred steer calves $(299 \pm 0.6 \mathrm{~kg})$ were used in a completely randomized design with six dietary treatments (four pens per treatment). Treatments were six concentrations of wet corn gluten feed (Sweet Bran, Cargill Inc., Blair, NE; 0, 10, 20, 25, 30, and 35\%) replacing steamflaked corn (DM basis). All diets contained 10\% corn silage, 5\% supplement, and 3.5\% tallow (DM basis). Gain efficiency and ADG were similar $(P>0.25)$ among treatments. Dry matter intake was lower $(P<0.10)$ with $0 \%$ wet corn gluten feed than with concentrations of 20, 25, and 35\% WCGF. Dry matter intake did not differ among treatments containing wet corn gluten feed. In Exp. 2, 160 English $\times$ Continental crossbred steer calves $(315 \pm 0.6 \mathrm{~kg})$ were used in a completely randomized design with five dietary treatments (four pens/treatment). Treatments were assigned based on four ratios of steep to corn bran/germ meal mix in wet
\end{abstract}

corn gluten feed plus a negative control (CON). Wet corn gluten feed was fed at $25 \%$ of the dietary DM and was made by mixing steep and corn bran/germ meal into the diet. The four concentrations of steep in wet corn gluten feed that comprised the ratios were 37.5, 41.7, 45.8, and 50\% (DM basis), with the remaining proportion being the bran/germ meal mix. Bran/germ meal mix was comprised of $60 \%$ dry corn bran, $24 \%$ germ meal, and 16\% fine-cracked corn (DM basis). All diets contained $10 \%$ corn silage, $5 \%$ supplement, and $3.5 \%$ tallow (DM basis). Daily gain did not differ $(P=$ 0.18 ) among treatments. Gain efficiency did not differ between CON and 50\% steep; however, G:F was decreased $(P<0.05)$ for concentrations of $37.5,41.7$, and $45.8 \%$ steep compared with CON. A linear improvement $(P<0.05)$ was observed for $\mathrm{G}: \mathrm{F}$ as concentration of steep increased as a proportion of wet corn gluten feed. These data suggest that wet corn gluten feed can be used at concentrations up to $35 \%$ of the dietary DM without adversely affecting performance, and that steep has more energy than bran/germ meal in steam-flaked cornbased diets.

Key Words: Corn Gluten Feed, Finishing Cattle, Steam Flaking

(C2004 American Society of Animal Science. All rights reserved.

J. Anim. Sci. 2004. 82:2718-2723

\section{Introduction}

Wet corn gluten feed (WCGF) is a by-product of the corn wet milling industry and is comprised primarily of steep liquor (liquid resulting from steeping corn) and corn bran. However, depending on wet milling plant capabilities, WCGF may also contain distiller solubles, germ meal, and kernel screenings (Stock et al., 2000). Feeding WCGF in dry-rolled corn (DRC)-based finish-

\footnotetext{
${ }^{1}$ A contribution of the Univ. of Nebraska Agric. Res. Div., Lincoln, NE 68583. Journal Series No. 14360. This research was supported in part by funds provided through the Hatch Act.

${ }^{2}$ Correspondence: C220 Animal Science (phone: 402-472-6450; fax: 402-472-6362; e-mail: gerickson4@unl.edu).

Received October 30, 2003.

Accepted May 26, 2004.
}

ing diets has been shown to increase intake and gain, while maintaining or improving feed efficiency (Stock et al., 2000). The energy concentration of WCGF can vary and has been associated with the proportion of steep in WCGF (Stock et al., 2000). Steep contains more energy than corn bran (Scott et al., 1997b) and germ meal (Herold et al., 1998), the other components of WCGF, when fed in DRC based finishing diets.

The majority of the research conducted with WCGF and its components has been in DRC-based diets. Cattle efficiency responses to WCGF in steam-flaked corn (SFC)-based finishing diets (Sindt et al., 2002) have differed from responses shown in DRC-based diets (Ham et al., 1995; Scott et al., 1997a). However, in Sindt et al. (2002), 0, 30, and 60\% of diet DM were evaluated, and replacing $30 \%$ of SFC was equal to SFC diets alone. However, only three concentrations were evaluated. 
Table 1. Finishing diet ingredient composition, DM basis (Exp. 1)

\begin{tabular}{|c|c|c|c|c|c|c|}
\hline \multirow[b]{2}{*}{ Ingredient, \% } & \multicolumn{6}{|c|}{ Treatments $^{\mathrm{a}}$} \\
\hline & $0 \%$ & $10 \%$ & $20 \%$ & $25 \%$ & $30 \%$ & $35 \%$ \\
\hline Steam-flaked corn & 81.5 & 71.5 & 61.5 & 56.5 & 51.5 & 46.5 \\
\hline Wet corn gluten feed & - & 10.0 & 20.0 & 25.0 & 30.0 & 35.0 \\
\hline Corn silage & 10.0 & 10.0 & 10.0 & 10.0 & 10.0 & 10.0 \\
\hline Tallow & 3.5 & 3.5 & 3.5 & 3.5 & 3.5 & 3.5 \\
\hline Dry meal supplement & 5.0 & 5.0 & 5.0 & 5.0 & 5.0 & 5.0 \\
\hline Urea & 1.81 & 1.38 & 0.96 & 0.75 & 0.53 & 0.32 \\
\hline Limestone & 1.73 & 1.72 & 1.71 & 1.71 & 1.71 & 1.70 \\
\hline Potassium chloride & 0.47 & 0.34 & 0.20 & 0.14 & 0.07 & - \\
\hline Ammonium sulfate & 0.40 & 0.29 & 0.17 & 0.11 & 0.06 & - \\
\hline Sodium chloride & 0.30 & 0.30 & 0.30 & 0.30 & 0.30 & 0.30 \\
\hline Tallow & 0.15 & 0.15 & 0.15 & 0.15 & 0.15 & 0.15 \\
\hline Trace mineral premix ${ }^{b}$ & 0.05 & 0.05 & 0.05 & 0.05 & 0.05 & 0.05 \\
\hline Fine ground milo & 0.05 & 0.73 & 1.42 & 1.75 & 2.09 & 2.44 \\
\hline Rumensin-80 premix $^{c}$ & 0.02 & 0.02 & 0.02 & 0.02 & 0.02 & 0.02 \\
\hline Tylan-40 premix ${ }^{\mathrm{d}}$ & 0.01 & 0.01 & 0.01 & 0.01 & 0.01 & 0.01 \\
\hline Vitamin premix ${ }^{\mathrm{e}}$ & 0.01 & 0.01 & 0.01 & 0.01 & 0.01 & 0.01 \\
\hline \multicolumn{7}{|l|}{ Analyzed composition } \\
\hline $\mathrm{DM}, \%$ & 73.5 & 71.0 & 68.8 & 67.7 & 66.6 & 65.6 \\
\hline $\mathrm{CP}, \%^{\mathrm{f}}$ & 14.1 & 14.3 & 14.5 & 14.6 & 14.7 & 14.7 \\
\hline
\end{tabular}

${ }^{\mathrm{a} C}$ Concentration of WCGF inclusion (DM basis).

${ }^{\mathrm{b}}$ Contained (g/kg of premix): $130 \mathrm{Ca}, 10 \mathrm{Co}, 15 \mathrm{Cu}, 2 \mathrm{I}, 100 \mathrm{Fe}, 80 \mathrm{Mn}$, and $120 \mathrm{Zn}$.

${ }^{\mathrm{c}}$ Diet formulated to contain $34 \mathrm{mg} / \mathrm{kg}$ of monensin (176 g of monensin/ $\mathrm{kg}$ of premix).

${ }^{\mathrm{d} D i e t}$ formulated to contain $11 \mathrm{mg} / \mathrm{kg}$ of tylosin ( $88 \mathrm{~g}$ of monensin $/ \mathrm{kg}$ of premix).

${ }^{\mathrm{e}}$ Contained 29.9 million IU of vitamin A, 6.0 million IU of vitamin D, and 7,000 IU of vitamin E/kg of premix.

${ }^{\mathrm{f}} \mathrm{CP}$ values were analyzed and equal for both Phases 1 and 2 . The only change was replacing the urea and feather meal:blood meal combination.

Therefore, the objectives of these studies were 1) to determine the optimal concentration of WCGF and 2) to evaluate the interaction of steep and corn bran/germ meal concentration of WCGF in SFC-based diets fed to finishing cattle.

\section{Materials and Methods}

\section{Experiment 1}

One hundred ninety-two English $\times$ Continental crossbred steer calves $(299 \pm 0.6 \mathrm{~kg})$ were stratified by BW (eight BW strata) and assigned randomly to one of 24 open-lot pens (eight steers per pen). Pens were assigned randomly to one of six dietary treatments (four pens per treatment). Treatments were assigned based on six concentrations of Sweet Bran (Cargill Inc., Blair, NE) WCGF in SFC-based diets. Concentrations were 0, 10, 20, 25, 30, and 35\% WCGF (DM basis), and WCGF replaced SFC in the diets. Steam-flaked corn was processed to a flake density of $0.34 \mathrm{~kg} / \mathrm{L}(26 \mathrm{lb} / \mathrm{bushel})$ at a commercial feedlot (Mead Cattle Co., Mead, NE) and delivered twice per week. Flake density was measured by flake thickness (Zinn, 1990). All diets contained 3.5\% tallow and $10 \%$ corn silage (DM basis). Steers were adapted to finishing diets in $29 \mathrm{~d}$ using SFC to replace alfalfa hay ( $35 \%$ alfalfa hay for $7 \mathrm{~d}, 25 \%$ for $8 \mathrm{~d}, 15 \%$ for $7 \mathrm{~d}$, and $5 \%$ for $7 \mathrm{~d}$, DM basis). Feed ingredients were sampled on a weekly basis to correct DM in the diets. Supplements were fed in two phases to supply undegraded intake protein (UIP) early in the finishing stage when calves may be deficient in metabolizable protein (MP). In Phase 1, UIP was supplemented to calves using feather and blood meal (50:50 ratio) at 1\% of dietary DM. In Phase 2, UIP was replaced with urea when cattle were estimated to weigh $398 \mathrm{~kg}$. This occurred on d 41 of the feeding period. Diets (Table 1) were formulated (DM basis) to contain a minimum of $14.0 \% \mathrm{CP}, 0.70 \% \mathrm{Ca}, 0.51 \% \mathrm{P}, 0.65 \% \mathrm{~K}, 34 \mathrm{mg} / \mathrm{kg}$ of monensin (Elanco Animal Health, Indianapolis, IN), and $11 \mathrm{mg} / \mathrm{kg}$ of tylosin (Elanco Animal Health). Diets were formulated to meet protein requirements using the 1996 NRC beef cattle model at two stages: the beginning of Phases 1 and 2 (Table 2). Protein analysis was determined on feeds from total $\mathrm{N}$ analysis by combustion method using a N analyzer (Leco FP428, Leco Corp., St. Joseph, MI). Bacterial protein efficiency was increased $20 \%$ for the proportion of SFC that was included in the diet, based on the data of Cooper et al. (2002).

Steers were vaccinated with Pyramid MLV 4 (Fort Dodge Animal Health, Overland Park, KS), Presponse HM (Fort Dodge Animal Health), and Vision 7 with somnus (Intervet, Millsboro, DE) and poured with Cydectin (Fort Dodge Animal Health) upon arrival to the feedlot (35 to $50 \mathrm{~d}$ before initiation of the trial). Steers were implanted initially $(0 \mathrm{~d})$ with Synovex-C (10 mg of estradiol benzonate and $100 \mathrm{mg}$ of progesterone; Fort Dodge Animal Health) and reimplanted with Revalor$\mathrm{S}$ (24 mg of estradiol and $120 \mathrm{mg}$ of trenbolone acetate; 
Table 2. The NRC (1996) beef cattle model formulated metabolizable protein balances for Phases 1 and 2 of protein supplementation (Exp. 1)

\begin{tabular}{|c|c|c|c|c|c|c|}
\hline \multirow[b]{2}{*}{ Item } & \multicolumn{6}{|c|}{ Treatments $^{\mathrm{a}}$} \\
\hline & $0 \%$ & $10 \%$ & $20 \%$ & $25 \%$ & $30 \%$ & $35 \%$ \\
\hline \multicolumn{7}{|l|}{ Phase $1^{\mathrm{b}}$} \\
\hline \multicolumn{7}{|l|}{$\mathrm{MP}^{\mathrm{c}}$} \\
\hline Supplied, g/d & 761 & 767 & 771 & 771 & 774 & 776 \\
\hline Required, g/d & 764 & 764 & 764 & 764 & 764 & 764 \\
\hline Balance, g/d & -3 & 3 & 7 & 7 & 10 & 12 \\
\hline \multicolumn{7}{|l|}{$\mathrm{DIP}^{\mathrm{c}}$} \\
\hline Supplied, g/d & 694 & 692 & 689 & 688 & 686 & 685 \\
\hline Required, g/d & 667 & 671 & 671 & 672 & 674 & 676 \\
\hline Balance, g/d & 27 & 22 & 18 & 16 & 12 & 9 \\
\hline \multicolumn{7}{|l|}{ Phase $2^{\mathrm{d}}$} \\
\hline \multicolumn{7}{|l|}{$\mathrm{MP}$} \\
\hline Supplied, g/d & 843 & 849 & 855 & 858 & 860 & 863 \\
\hline Required, g/d & 776 & 776 & 776 & 776 & 776 & 776 \\
\hline Balance, $\mathrm{g} / \mathrm{d}$ & 67 & 73 & 79 & 82 & 84 & 87 \\
\hline \multicolumn{7}{|l|}{ DIP } \\
\hline Supplied, g/d & 871 & 866 & 861 & 859 & 856 & 854 \\
\hline Required, g/d & 778 & 762 & 785 & 787 & 788 & 789 \\
\hline Balance, $\mathrm{g} / \mathrm{d}$ & 93 & 84 & 76 & 72 & 68 & 65 \\
\hline
\end{tabular}

${ }^{\mathrm{a}}$ Concentration of wet corn gluten feed inclusion (DM basis).

${ }^{\mathrm{b}}$ Supplied UIP from feather meal and blood meal (50:50) and fed for the first $40 \mathrm{~d}$. Inputs for cattle entered into the model were: $\mathrm{BW}=318 \mathrm{~kg} ; \mathrm{ADG}=1.63 \mathrm{~kg} ; \mathrm{DMI}=8.0 \mathrm{~kg} / \mathrm{d}$; and final $\mathrm{BW}=591 \mathrm{~kg}$.

${ }^{\mathrm{c}} \mathrm{MP}=$ metabolizable protein, $\mathrm{DIP}=$ degraded intake protein, and UIP = undegraded intake protein.

dUrea replaced the UIP supplementation and fed for the last $111 \mathrm{~d}$. Inputs for cattle entered into the model were: $\mathrm{BW}=523 \mathrm{~kg} ; \mathrm{ADG}=1.63 \mathrm{~kg} ; \mathrm{DMI}=9.3 \mathrm{~kg} / \mathrm{d}$; and final $\mathrm{BW}=591 \mathrm{~kg}$.

Intervet) on d 53. Steers were fed for $151 \mathrm{~d}$. Steers were fed once daily between 0800 and 1100 using a Roto-Mix 420-12 mixer with a $0.45-\mathrm{kg}$ scale break and allowed ad libitum access to feed and water.

Initial BW were obtained on individual steers with a scale break of $0.45 \mathrm{~kg}$ on two consecutive days after being limit fed at $2 \%$ (DM basis) of BW for $5 \mathrm{~d}$ to minimize ruminal fill differences. Final weight was calculated from hot carcass weight divided by $63 \%$. Daily gain, DMI, and G:F were calculated on a pen basis. Hot carcass weights were collected on all steers at the time of slaughter, whereas other carcass traits were collected following a 24 -h chill. Dietary $\mathrm{NE}_{\mathrm{g}}$ concentrations were calculated, based on performance, using the iterative procedure described by Owens et al. (2002).

Data were analyzed as a completely randomized design using the MIXED procedure of SAS (SAS Inst., Inc., Cary, NC), with pen as experimental unit. Treatment was used in the model statement. Least squares means were separated using the LSD method when a significant $(P<0.05)$ overall $F$-test was detected. Linear, quadratic, and cubic effects were tested for concentration of WCGF using regression procedures in the MIXED procedure for unequally spaced treatments. Procedures for the study had been reviewed and accepted by the University of Nebraska Institutional Animal Care Program.

\section{Experiment 2}

One hundred sixty English $\times$ Continental crossbred steer calves $(315 \pm 0.6 \mathrm{~kg}$ ) were stratified by BW (eight
BW strata) and assigned randomly to one of 20 openlot pens (eight steers per pen). Pens were assigned randomly to one of five dietary treatments (four pens per treatment). Treatments were assigned based on four ratios of steep liquor plus distiller solubles (steep) to a corn bran/germ meal mix (B/GM) in WCGF, plus a negative control (CON) without WCGF. Wet corn gluten feed was fed at $25 \%$ of dietary DM and was made by mixing steep and B/GM into the diet. The B/GM was mixed weekly and added to the diet as one ingredient. The B/GM mix was $60 \%$ corn dry bran, $24 \%$ germ meal, and 16\% fine-cracked corn (DM basis). The B/GM and steep were mixed into the diet as separate ingredients to produce four concentrations of steep in the WCGF: $37.5 \%$ steep; $41.7 \%$ steep; $45.8 \%$ steep; and $50.0 \%$ steep (DM basis, Table 3). Steam-flaked corn was processed to a flake density of $0.34 \mathrm{~kg} / \mathrm{L}$ (26 lb/bushel) at a commercial feedlot (Mead Cattle Co.) and delivered twice per week. All diets fed contained 3.5\% tallow and 10\% corn silage (DM basis). Steers were adapted to finishing diets in $21 \mathrm{~d}$ using SFC to replace alfalfa hay $(35 \%$ alfalfa hay for $3 \mathrm{~d}, 25 \%$ for $4 \mathrm{~d}, 15 \%$ for $7 \mathrm{~d}$, and $5 \%$ for $7 \mathrm{~d}$, DM basis). Feed ingredients were sampled on a weekly basis to correct DM in the diets. Supplements were fed in two phases similar to Trial 1 and switched when cattle were estimated to weigh $432 \mathrm{~kg}$. This occurred on d 65 of the feeding period. Diets (Table 3) were formulated (DM basis) to contain a minimum of $14.0 \% \mathrm{CP}, 0.70 \% \mathrm{Ca}, 0.51 \% \mathrm{P}, 0.65 \% \mathrm{~K}, 34 \mathrm{mg} / \mathrm{kg}$ of monensin, and $11 \mathrm{mg} / \mathrm{kg}$ tylosin. Formulation of MP balances and protein analysis were similar to Exp. 1. 
Table 3. Finishing diet ingredient composition, DM basis (Exp. 2)

\begin{tabular}{|c|c|c|c|c|c|}
\hline \multirow[b]{2}{*}{ Ingredient, \% } & \multicolumn{5}{|c|}{ Treatments $^{\mathrm{a}}$} \\
\hline & $\mathrm{CON}$ & $37.5 \% \mathrm{ST}$ & $41.7 \% \mathrm{ST}$ & $45.8 \% \mathrm{ST}$ & $50.0 \% \mathrm{ST}$ \\
\hline Steam-flaked corn & 81.5 & 56.5 & 56.5 & 56.5 & 56.5 \\
\hline Corn silage & 10.0 & 10.0 & 10.0 & 10.0 & 10.0 \\
\hline Tallow & 3.5 & 3.5 & 3.5 & 3.5 & 3.5 \\
\hline Steep & - & 9.4 & 10.4 & 11.5 & 12.5 \\
\hline \multicolumn{6}{|l|}{ Bran/GM mix ${ }^{b}$} \\
\hline Bran & - & 9.4 & 8.8 & 8.1 & 7.5 \\
\hline Germ meal & - & 3.8 & 3.5 & 3.3 & 3.0 \\
\hline Fine-cracked corn & - & 2.5 & 2.3 & 2.2 & 2.0 \\
\hline Dry meal supplement & 5.0 & 5.0 & 5.0 & 5.0 & 5.0 \\
\hline Urea & 1.81 & 0.89 & 0.83 & 0.78 & 0.72 \\
\hline Limestone & 1.73 & 1.71 & 1.71 & 1.71 & 1.71 \\
\hline Potassium chloride & 0.47 & - & - & - & - \\
\hline Ammonium sulfate & 0.40 & 0.14 & 0.12 & 0.10 & 0.08 \\
\hline Sodium chloride & 0.30 & 0.30 & 0.30 & 0.30 & 0.30 \\
\hline Tallow & 0.15 & 0.15 & 0.15 & 0.15 & 0.15 \\
\hline Trace mineral premix ${ }^{c}$ & 0.05 & 0.05 & 0.05 & 0.05 & 0.05 \\
\hline Fine ground milo & 0.05 & 1.72 & 1.80 & 1.87 & 1.95 \\
\hline Rumensin-80 premix ${ }^{\mathrm{d}}$ & 0.02 & 0.02 & 0.02 & 0.02 & 0.02 \\
\hline Tylan-40 premix & 0.01 & 0.01 & 0.01 & 0.01 & 0.01 \\
\hline Vitamin premix ${ }^{f}$ & 0.01 & 0.01 & 0.01 & 0.01 & 0.01 \\
\hline \multicolumn{6}{|l|}{ Analyzed composition } \\
\hline $\mathrm{DM}, \%$ & 73.5 & 69.0 & 68.5 & 67.9 & 67.5 \\
\hline $\mathrm{CP}, \%$ & 14.1 & 14.6 & 14.6 & 14.7 & 14.7 \\
\hline \multicolumn{6}{|c|}{ 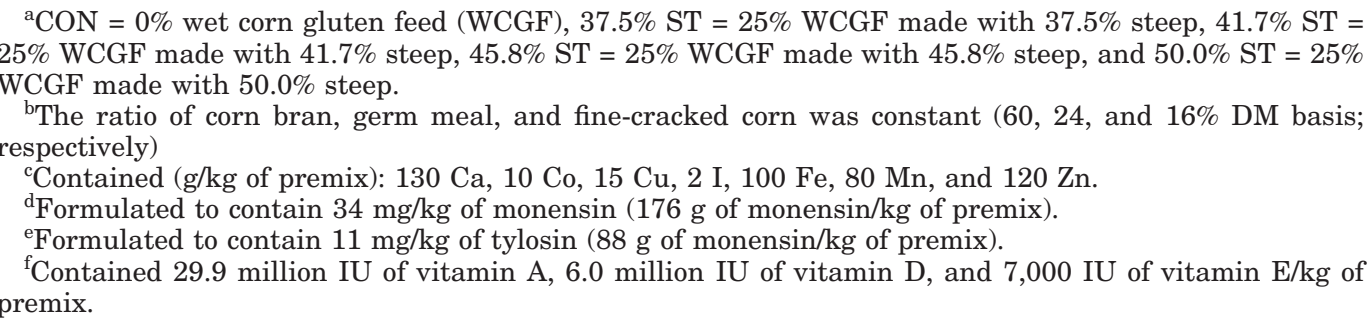 } \\
\hline
\end{tabular}

Steers were vaccinated as in Exp. 1, but initiation of Exp. 2 was $42 \mathrm{~d}$ after the initiation of Exp. 1. Steers were implanted initially $(0 \mathrm{~d})$ with Synovex C (Fort Dodge Animal Health) and reimplanted with Revalor$\mathrm{S}$ (Intervet) on d 46. Steers were fed for $132 \mathrm{~d}$. Steers were fed once daily between 0800 and 1100 using a Roto-Mix 420-12 mixer with a $0.45-\mathrm{kg}$ scale break and were allowed ad libitum access to feed and water. Response criteria and measurements for cattle performance and carcass characteristics were similar to Exp. 1.

Data were analyzed as a completely randomized design using the MIXED procedure of SAS with pen as the experimental unit. Treatment was used in the model statement. Least squares means were separated using the LSD method when a significant $(P<0.05)$ overall $F$-test was detected. Linear, quadratic, and cubic effects were tested for concentration of steep. Procedures for the studies were reviewed and approved by the University of Nebraska Institutional Animal Care Program.

\section{Results and Discussion}

\section{Experiment 1}

Final weights, ADG, and G:F did not differ $(P>0.25)$ among treatments (Table 4$)$ resulting in similar $(P=$
$0.29)$ dietary $\mathrm{NE}_{\mathrm{g}}$ concentrations. However, a tendency for a linear effect was observed $(P=0.07)$ for DMI, such that DMI increased in response to increasing concentration of WCGF. The linear effect on inclusion concentration of WCGF on DMI is consistent with previous reports using SFC- (Block et al., 2002; Sindt et al., 2002) and DRC-based diets (Scott et al. 1997a). Block et al. (2002) reported a quadratic effect for ADG and feed efficiency for concentrations of WCGF of $0,20,30$, and $40 \%$ of diet DM, optimizing in the range of 20 to $30 \%$ inclusion. These concentrations differed slightly from the concentrations fed in our study $(0,10,20,25,30$, and $35 \%)$. Potentially, the difference in concentrations may account for differences across experiments. The $10 \%$ concentration of WCGF in our study seems to have had some negative effect on feed efficiency and dietary $\mathrm{NE}_{\mathrm{g}}$. Feeding 40\% WCGF (DM basis) in SFC-based diets decreased G:F (Parsons et al. 2001; Block et al. 2002; Sindt et al. 2002) compared with no inclusion of WCGF in finishing diets. With these considerations, feeding $10 \%$ concentration and not feeding a $40 \%$ concentration may explain the lack of quadratic response. Hot carcass weight, marbling, fat thickness, LM area, and USDA yield grade did not differ $(P>0.47)$ among treatments (Table 4$)$. These data would suggest that 
Table 4. Effect of WCGF concentration in steam-flaked corn-based diets on cattle performance and carcass characteristics (four pens per treatment)

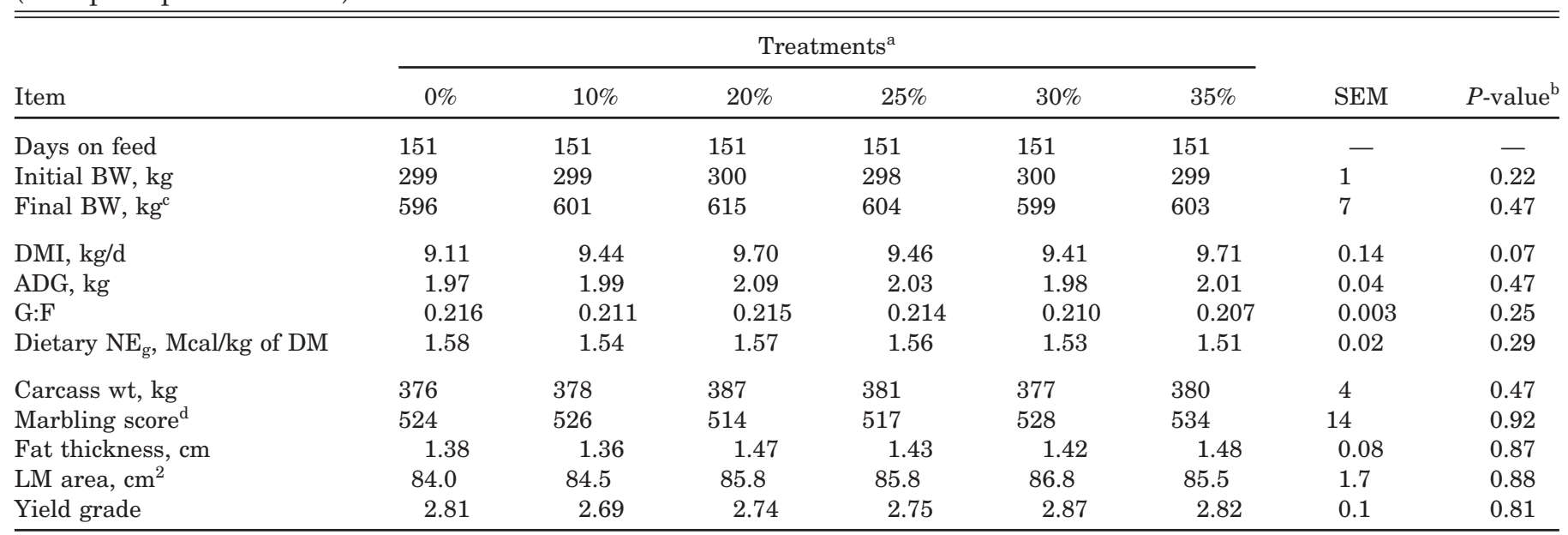

${ }^{\mathrm{a} C o n c e n t r a t i o n}$ of wet corn gluten feed inclusion (DM basis).

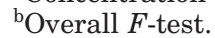

cFinal weight calculated as hot carcass weight divided by 0.63 .

${ }^{\mathrm{d}}$ Marbling score: $400=$ Slight 0, $450=$ Slight 50, $500=$ Small 0, $550=$ Small 50, etc.

concentrations up to $35 \%$ WCGF can be fed with steamflaked corn-based diets.

\section{Experiment 2}

Cattle fed steep and B/GM (25\% of diet DM) had greater $(P<0.05)$ DMI compared with the cattle fed CON (Table 5). The response at this concentration of inclusion is similar to results observed in Trial 1 and results previously reported (Block et al., 2002; Sindt et al., 2002) when WCGF replaced SFC in finishing diets. Within steep and B/GM, a quadratic response $(P<0.05)$ was observed for DMI, with DMI being greatest for the 41.7 and $45.8 \%$ steep concentrations. Herold (1999) reported a quadratic response to the ratio of steep to bran and a linear response to the ratio of steep to B/ GM in DRC-based finishing diets. The range of steep percentage in the Herold (1999) study (20 to 50\%, DM basis) was greater than the range used in our study (37.5 to 50\%, DM basis), and the range in steep may

Table 5. Cattle performance and carcass characteristics with different steep to corn bran/ germ meal ratios in wet corn gluten feed (WCGF) added to steam-flaked corn-based diets (four pens per treatment)

\begin{tabular}{|c|c|c|c|c|c|c|c|}
\hline \multirow[b]{2}{*}{ Item } & \multicolumn{5}{|c|}{ Treatments $^{\mathrm{a}}$} & \multirow[b]{2}{*}{ SEM } & \multirow[b]{2}{*}{$P$-value ${ }^{\mathrm{b}}$} \\
\hline & $\mathrm{CON}$ & $37.5 \% \mathrm{ST}$ & $41.7 \% \mathrm{ST}$ & $45.8 \% \mathrm{ST}$ & $50.0 \% \mathrm{ST}$ & & \\
\hline Days on feed & 132 & 132 & 132 & 132 & 132 & & \\
\hline Initial BW, kg & 315 & 314 & 316 & 314 & 315 & 1 & 0.12 \\
\hline Final BW, $\mathrm{kg}^{\mathrm{c}}$ & 601 & 598 & 611 & 610 & 610 & 5 & 0.19 \\
\hline DMI, kg/d & $9.58^{\mathrm{g}}$ & $10.30^{\mathrm{h}}$ & $10.46^{\mathrm{h}}$ & $10.48^{\mathrm{h}}$ & $10.19^{\mathrm{h}}$ & 0.10 & $<0.01$ \\
\hline $\mathrm{ADG}, \mathrm{kg}$ & 2.16 & 2.15 & 2.24 & 2.24 & 2.24 & 0.04 & 0.18 \\
\hline $\mathrm{G}: \mathrm{F}^{\mathrm{e}}$ & $0.226^{\mathrm{g}}$ & $0.208^{\mathrm{i}}$ & $0.214^{\mathrm{hi}}$ & $0.214^{\mathrm{hi}}$ & $0.220^{\mathrm{gh}}$ & 0.003 & 0.02 \\
\hline Dietary $\mathrm{NE}_{\mathrm{g}}, \mathrm{Mcal} / \mathrm{kg}$ of $\mathrm{DM}^{\mathrm{e}}$ & $1.64^{\mathrm{g}}$ & $1.51^{\mathrm{i}}$ & $1.55^{\mathrm{hi}}$ & $1.55^{\mathrm{hi}}$ & $1.59^{\mathrm{gh}}$ & 0.02 & 0.02 \\
\hline Carcass wt, kg & 379 & 377 & 385 & 384 & 385 & 3 & 0.18 \\
\hline Marbling score ${ }^{\mathrm{f}}$ & 516 & 533 & 531 & 538 & 528 & 9 & 0.55 \\
\hline Fat thickness, cm & $1.25^{\mathrm{g}}$ & $1.42^{\mathrm{gh}}$ & $1.48^{\mathrm{h}}$ & $1.60^{\mathrm{h}}$ & $1.47^{\mathrm{h}}$ & 0.07 & 0.03 \\
\hline $\mathrm{LM}$ area, $\mathrm{cm}^{2}$ & 107.0 & 100.8 & 103.7 & 100.5 & 103.9 & 1.5 & 0.06 \\
\hline Yield grade & $2.38^{\mathrm{g}}$ & $2.85^{\mathrm{h}}$ & $2.81^{\mathrm{h}}$ & $2.83^{\mathrm{h}}$ & $2.82^{\mathrm{h}}$ & 0.11 & 0.04 \\
\hline
\end{tabular}

${ }^{\mathrm{a}} \mathrm{CON}=0 \%$ WCGF, 37.5 ST $=25 \%$ WCGF made with $37.5 \%$ steep, $41.7 \mathrm{ST}=25 \%$ WCGF made with $41.7 \%$ steep, $45.8 \mathrm{ST}=25 \%$ WCGF made with $45.8 \%$ steep, and 50.0 ST= 25\% WCGF made with $50.0 \%$ steep.

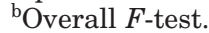

${ }^{\mathrm{c}}$ Final weight calculated as hot carcass weight divided by 0.63 .

${ }^{\mathrm{d}}$ Quadratic effect of steep percentage of WCGF $(P<0.05)$.

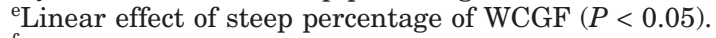

${ }^{\mathrm{f}}$ Marbling score: $400=$ Slight $0,450=$ Slight $50,500=$ Small 0 , etc.

g,h,i Means within a row with different superscripts differ $(P<0.05)$. 
explain the different response between this study and other experiments.

Daily gain did not differ $(P=0.18)$ among treatments, although there was a linear trend $(P=0.09)$ for ADG to increase as steep concentration increased. Compared with the CON, feeding wet milling by-products did not affect $(P=0.18)$ ADG, which was similar to the response observed in Exp. 1. Gain efficiency did not differ between $\mathrm{CON}$ and $50.0 \%$ steep. A linear improvement $(P$ $<0.05$ ) in G:F was detected as the percentage of steep increased, suggesting that steep has a higher energy value than B/GM meal in SFC-based diets. This response is similar to the response observed in DRC-based diets (Herold 1999). Scott et al. (1997b) and Herold et al. (1998) reported that the energy value of steep was greater than that of corn bran and germ meal, respectively, in DRC-based finishing diets.

Hot carcass weight, LM area, and marbling score did not differ among treatments. Cattle fed CON had less $(P<0.05)$ fat and lower USDA yield grades than did those fed steep and B/GM, suggesting that the CON cattle were not finished to the same end point as the steep and B/GM cattle. Presumably, G:F for the CON cattle would have been less if they had been fed to the same fat thickness as the cattle fed the by-products. Therefore, it is unclear from the G:F data as to whether CON cattle were more efficient due to diet energy or composition of gain. It also is unclear how one might correct for such composition of gain effects on feed efficiency.

\section{Implications}

Replacing steam-flaked corn with wet corn gluten feed up to $35 \%$ of diet DM had minimal effects on finishing cattle performance. Steep liquor plus distiller solubles content of wet corn gluten feed can affect the feeding value of wet corn gluten feed in finishing cattle diets. A higher percentage of steep in wet corn gluten feed increased energy value and improved cattle performance. Therefore, knowing the composition of wet corn gluten feed is important to determine the response that will be observed with the replacement of steam-flaked corn with wet corn gluten feed in finishing beef cattle diets.

\section{Literature Cited}

Block, H., C. Macken, T. Klopfenstein, R. Cooper, and R. Stock. 2002. Crude protein and wet corn gluten feed levels for steam flaked corn finishing diets. Pages 68-71 in NE Beef Cattle Rep. MP 79-A. Univ. of Nebraska, Lincoln.

Cooper, R. J., C. T. Milton, T. J. Klopfenstein, and D. J. Jordon. 2002. Effect of corn processing on degradable intake protein requirement of finishing cattle. J. Anim. Sci. 80:242-247.

Ham, G. A., R. A. Stock, T. J. Klopfenstein, and R. P. Huffman. 1995. Determining the net energy value of wet and dry corn gluten feed in beef growing and finishing diets. J. Anim. Sci. 73:353-359.

Herold, D. W. 1999. Solvent-extracted germ meal for ruminants. Ph. D. Diss., Univ. of Nebraska, Lincoln.

Herold, D., M. Klemesrud, T. Klopfenstein, T. Milton, and R. Stock. 1998. Solvent-extracted germ meal, corn bran, and steep liquor blends for finishing diets. Pages 50-53 in NE Beef Cattle Rep. MP69-A. Univ. of Nebraska, Lincoln.

Owens, F. N., M. A. Hinds, and D. W. Rice. 2002. Methods for calculating diet energy values from feedlot performance of cattle. J. Anim. Sci. 80(Suppl. 1):273. (Abstr.)

Parsons, C. H., M. L. Galyean, G. A. Nunnery, P. J. Defoor, and G. B. Salyer. 2001. Effects of Sweet Bran brand corn gluten feed and roughage level on performance and carcass characteristics of finishing beef cattle. Burnett Center Internet Prog. Rep. No. 9. Available: http://www.asft.ttu.edu/burnett_center/progess_ reports. Accessed June 11, 2003.

Scott, T., T. Klopfenstein, D. Shain, and M. Klemesrud. 1997a. Wet corn gluten feed as a source of rumen degradable protein for finishing steers. Pages 70-72 in NE Beef Cattle Rep. MP67-A. Univ. of Nebraska, Lincoln.

Scott, T., T. Klopfenstein, R. Stock, and M. Klemesrud. 1997b. Evaluation of corn bran and corn steep liquor for finishing steers. Pages 72-74 in NE Beef Cattle Rep. MP67-A. Univ. of Nebraska, Lincoln.

Sindt, J. J., J. S. Drouillard, H. Thippareddi, R. K. Phebus, D. L. Lambert, S. P. Montgomery, T. B. Farran, H. J. LaBrune, J. J. Higgins, and R. T. Ethington. 2002. Evaluation of finishing performance, carcass characteristics, acid-resistant $E$. coli and total coliforms from steers fed combination of wet corn gluten feed and steam-flaked corn. J. Anim. Sci. 80:3328-3335.

Stock, R. A., J. M. Lewis, T. J. Klopfenstein, and C. T. Milton. 2000. Review of new information on the use of wet and dry milling feed by-products in feedlot diets. Proc. Am. Soc. Anim. Sci., 1999. Available: http://www.asas.org/jas/symposia/proceedings/0924 .pdf. Accessed May 29, 2003.

Zinn, R. A. 1990. Influence of steaming time on site of digestion of flaked corn in steers. J. Anim. Sci. 68:776-781. 